capable of taking cores of the bottom sediment up to $30 \mathrm{ft}$. in depth. The seismic work will consist of refraction 'shooting' at short range (that is, up to a distance of twenty miles) in shallow water, and at long range (up to a hundred miles) on the edge of the continental slope, on the slope itself, and in oceanic depths ; for the short-range work only one ship, equipped with sono-radio buoys, is required, but two ships are necescary for the long-range observations, and H.M.S. Scott will assist in this. Other work to be attempted during the cruise will include heat-flow measurements through the bed of the ocean, at a depth of about 2,000 fathoms $(12,000$ ft.), these observations being made with a specially devised probe which is driven $10 \mathrm{ft}$. into the bottom sediment and allowed to remain there for a specified time. The purpose of these measurements is to determine whether the heat-flow through a continent originates from radioactivity of the continental-type rocks which are, to a large extent, absent under the oceans. Wave recordings, with the special ship-borne wave recorder fitted for the previous cruise, will be continued as a normal routine, and special attention will be given to echo-sounding, more particularly on the continental slope and in deep water. The ship is operated by the National Institute of Oceanography ; during this voyage it will work in co-operation with the Department of Geodesy and Geophysics, University of Cambridge, and the following men of science, among otherz, will be on board during parts of the cruise: Dr. E. C. 1 ullard, director of the National Physical Laboratory, 'Teddington; Prof. W. B. R. King, Department of Geology, and Dr. M. N. Hill and Mr. B. C. Browne, of the Department of Geodesy and Geophysics, Cambridge ; and Dr. H. F. P. Herdman, of the National Institute of Oceanography.

\section{Indian Jute Mills Association Research Institute}

THE formal opening by the Prime Minister of India, Mr. Nehru, on January 2, of the new buildings of the Indian Jute Mills Association Research Institute in Calcutta completes the second part of the Association's post-war scheme of co-operative development, which had already been partly realized by the inauguration of a training college for apprentices (Nature, 167, 1058; 1951). The Research Institute, founded in 1936 to provide the type of service usually given by research associations in Britain, was originally housed in central Calcutta, under conditions which left a good deal to be desired by the scientific workers on the staff, and in 1945 it was decided to provide more adequate accommodation in the suburbs. The new premises provide modern amenities for a staff of 85 , including 45 qualified scientific men or technologists. Laboratories for physics (4), chemistry (4), biological sciences (3), $\mathrm{X}$-ray crystallography, optics, testing, dyeing, finishing, and chemical technology ; administrative offices, a lecture room, library, canteen, stores and workshop occupy most of the 50,000 sq. ft. of floor space in the two-storied air-conditioned building. Among the laboratory services are included laid-on compressed air and vacuum. In order to prepare the staff for making the best use of the new laboratories, senior members of the various sections (physics, chemistry, testing, etc.) have been sent to Great Britain during the past five or six years for training in research; the majority of these went to the University of Leeds and qualified for higher degrees in textile science or technology. The director of research of the Institute is Dr. W. G. Macmillan.

\section{Safety of Domestic Electrical Installations}

A PAPER entitled "Domestic Electrical Installations -Some Safety Aspects" was presented on January 24 to the Utilization Section of the Institution of Electrical Engineers by Mr. H. W. Swann, who is senior electrical inspector of the Factory Department of the Ministry of Labour and National Service. The paper gives a comprehensive review of the hazards commonly arising from electrical faults in domestic consumers' installations, and of the methods of protection employed and their limitations. Statistics relating to fires attributed to electrical causes are quoted for the period 1946-50, and attention is directed to the question of the effect of the age of electrical installations on fire risk. Detailed consideration is given to the effect of leakage current on fire and shock risks. It is emphasized that with the increased load now taken by many domestic consumers, normal fuse-settings are often sufficiently high to prevent operation with the maximum fault current that can flow in the 'earth loop', and in this connexion the advantages and limitations of earthleakage protection devices are discussed. It is suggested that changes in method may become necessary and that the inspection and test of protective devices may prove to be more practicable than large-scale inspection and test of installations and appliances already in use. The paper constitutes a much-needed reminder that means of protection of consumers' installations which were satisfactory at an earlier stage, when electrical energy was utilized on a much smaller scale than to-day, are being rendered ineffective by the sheer growth of the consumption of electricity.

\section{Training of Designers for the Printing Industry}

A rePORT on the training of designers for the printing industry prepared by a subcommittee of the London and Home Counties Regional Advisory Council, Higher Technological Education (Report No. 11 ; obtainable from the Council, Tavistock House South, London, W.C.1 ; pp. 20 ; 1952 ; 1s.), recommends that training courses for this purpose should be held in, or in association with, colleges containing reasonably comprehensive departments of printing. In allocating practical accommodation to classes in colleges, it is recommended that priority should be given to classes for apprentices under the indenture approved by the Joint Industrial Council. Local education authorities are recommended to ensure that their scholarship arrangements permit financial assistance for specially selected apprentices attending part-time classes to transfer to full-time attendance for a course in design, and trade associations should consider offering a limited number of scholarships to enable gifted apprentices to take full-time courses in design. Practical instruction in trade processes - to the limited extent recommended-should, for students in a four-year full-time design course, be confined to the last two years. The report is manifestly concerned solely with technical education-the basic principles by which the training of designers for the printing industry should be guided in the future. Nowhere in the report is there any concern with higher technological education, and on the evidence of this report the title itself of this Regional Advisory Council is one more illustration of the sad confusion between technical and higher technological education which appears to be impeding the formulation of an adequate and effective policy for either. 